\title{
Verbesina encelioides: cytotoxicity, cell cycle arrest, and oxidative DNA damage in human liver cancer (HepG2) cell line
}

\author{
Mai M. Al-Oqail ${ }^{1 \dagger}$, Maqsood A. Siddiquii, ${ }^{2,3 \dagger}$, Ebtesam S. Al-Sheddi ${ }^{1}$, Quaiser Saquib ${ }^{2,3}$, Javed Musarrat ${ }^{2,3}$, \\ Abdulaziz A. Al-Khedhairy ${ }^{2}$ and Nida N. Farshori ${ }^{1^{*}}$
}

\begin{abstract}
Background: Cancer is a major health problem and exploiting natural products have been one of the most successful methods to combat this disease. Verbesina encelioides is a notorious weed with various pharmacological properties.

The aim of the present investigation was to screen the anticancer potential of $V$. encelioides extract against human lung cancer (A-549), breast cancer (MCF-7), and liver cancer (HepG2) cell lines.

Methods: A-549, MCF-7, and HepG2 cells were exposed to various concentrations of $(10-1000 \mu \mathrm{g} / \mathrm{ml})$ of $\mathrm{V}$. encelioides for $24 \mathrm{~h}$. Further, cytotoxic concentrations (250,500, and $1000 \mu \mathrm{g} / \mathrm{ml}$ ) of $\mathrm{V}$. encelioides induced oxidative stress (GSH and LPO), reactive oxygen species (ROS) generation, mitochondrial membrane potential (MMP), cell cycle arrest, and DNA damage in HepG2 cells were studied.

Results: The exposure of cells to $10-1000 \mu \mathrm{g} / \mathrm{ml}$ of extract for $24 \mathrm{~h}$, revealed the concentrations 250$1000 \mathrm{\mu g} / \mathrm{ml}$ was cytotoxic against MCF-7 and HepG2 cells, but not against A-549 cells. Moreover, the extract showed higher decrease in the cell viability against HepG2 cells than MCF-7 cells. Therefore, HepG2 cells were selected for further studies viz. oxidative stress (GSH and LPO), reactive oxygen species (ROS) generation, mitochondrial membrane potential (MMP), cell cycle arrest, and DNA damage. The results revealed differential anticancer activity of $V$. encelioides against A-549, MCF-7 and HepG2 cells. A significant induction of oxidative stress, ROS generation, and MMP levels was observed in HepG2 cells. The cell cycle analysis and comet assay showed that $V$. encelioides significantly induced G2/M arrests and DNA damage.
\end{abstract}

Conclusion: These results indicate that $V$. encelioides possess substantial cytotoxic potential and may warrant further investigation to develop potential anticancer agent.

Keywords: Verbesina encelioides, Cytotoxicity, Oxidative stress, ROS generation, MMP, DNA damage

\section{Background}

Cancer is one of the main causes of human death in developed and developing countries [1-3]. 15 million new cases of cancer are expected, $70 \%$ of which will be in developing countries by 2020, where governments are less prepared to address the growing cancer burden [4]. Lung cancer, breast cancer, and liver cancer were

\footnotetext{
* Correspondence: nidachem@gmail.com

${ }^{\dagger}$ Equal contributors

'Department of Pharmacognosy, College of Pharmacy, King Saud University, Riyadh 11451, Kingdom of Saudi Arabia

Full list of author information is available at the end of the article
}

the most common sites of cancer diagnosed in 2012 among men and women [5]. The growing trend indicates deficiency in the present cancer therapies and the average survival rates are less [6]. An accurate and effective treatment of the cancer is very much required for diagnosis of the specific type of cancer diseases. Every cancer type requires a specific course of therapy that includes one or more modalities such as surgery, and/or radiotherapy, and/or chemotherapy $[7,8]$. Therefore, there is an urgent need to explore anti-cancer drugs with higher efficacy with less side effects and an affordable cost [9]. Chemotherapy is 
the most effective method of cancer treatment that uses chemical substances, especially one or more chemotherapeutic agents [10]. Alternative and complementary medicines play an emerging role in the cancer prevention. Plants are the best alternative, as they provide an infinite puddle of effective agents. Since many years, traditional remedies use phytochemicals to treat various diseases because of their inherent potential to cure diseases [11-16]. Among the alternative traditional approaches, various plant products classified as alkaloids, saponins, triterpenes, glycosides, and polyphenols have shown very promising anticancer properties in both in vitro and in vivo $[17,18]$.

Verbesina encelioides (VE), member of Asteraceae (Sunflower) family, is native to the United States, Mexican Plateau, Europe, and Asia including Saudi Arabia [19]. It is a notorious weed and an ornamental plant with various bio efficacies like antibacterial, antifungal, antiviral, hypoglycemic and implantation activities [20]. Traditionally $V$. encelioides finds use for the treatment of sore gums and hemorrhoids [21]. Phytochemical analysis of $V$. encelioides also revealed the presence of important primary metabolites, sesquiterpenes [22], flavonoids [23], galegine [24] and triterpenoids [25]. However, our literature survey revealed no published reports on the anticancer potential of aerial parts of $V$. encelioides. Thus, the present investigation aimed to explore the anticancer efficacy of $V$. encelioides alcoholic extract on human lung cancer (A-549), human breast cancer (MCF-7), and human liver cancer (HepG2) cell lines.

\section{Methods}

\section{Cell culture}

Human lung cancer (A-549), breast cancer (MCF-7), and liver cancer (HepG2) cell lines obtained from American Type Culture Collection (ATCC; Manassas, VA, USA), were grown in Dulbecco's modified eagle's medium (DMEM) supplemented with $10 \%$ fetal bovine serum (FBS), $0.2 \%$ sodium bicarbonate, and antibiotic/antimycotic solution $(1 \mathrm{ml} / 100 \mathrm{ml}$ of medium, Invitrogen, Life Technologies, USA). The cells were maintained in $5 \%$ $\mathrm{CO}_{2}$ and $95 \%$ atmosphere at $37^{\circ} \mathrm{C}$. Batches of cells showing more than $98 \%$ cell viability were used in the experiments. The cell viability was assessed by trypan blue dye exclusion assay following the protocol of Pant et al. [26].

\section{Reagents and consumables}

All the chemicals, culture mediums, reagents, and kits were procured from Sigma Chemical Company Pvt. Ltd., St. Louis, MO, USA. Culture wares and other plastic consumables used in the study were procured from Nunc, Denmark.

\section{Preparation of $V$. encelioids extract}

The $V$. encelioides plants used in this study were obtained from Harjah, Najran road, Saudi Arabia in October 2013. Dr. Mohammad Atiqur Rahman, taxonomist of Medicinal, Aromatic, and Poisonous Plants Research Center (MAPPRC), College of Pharmacy, King Saud University, Saudi Arabia identified the plants and a specimen (\#16048) is submitted in the herbarium of the King Saud University. The sundried plants were ground and extracted with methanol $(3 \times 10 \mathrm{~L})$ at room temperature. The combined methanol extract was evaporated under reduced pressure to obtain a thick gummy mass. The $V$. encelioides extract was diluted in dimethylsulphoxide (DMSO) for preparation of the various concentrations for cell viability and other assays.

\section{Experimental design}

A-549, MCF-7, and HepG2 cells were exposed to various concentrations of $(10-1000 \mu \mathrm{g} / \mathrm{ml})$ of $V$. encelioides for $24 \mathrm{~h}$. Further, cytotoxic concentrations $(250,500$, and $1000 \mu \mathrm{g} / \mathrm{ml}$ ) of $V$. encelioides induced oxidative stress (GSH and LPO), reactive oxygen species (ROS) generation, mitochondrial membrane potential (MMP), cell cycle arrest, and DNA damage in HepG2 cells were studied.

\section{Cytotoxicity assessments by MTT assay}

Percentage cell viability was assessed using the 3- $(4,5$ dimethylthiazol-2-yl)-2, 5-diphenyl tetrazolium bromide (MTT) assay following the protocol of Siddiqui et al. [27]. Briefly, 10,000 cells were plated in 96 well plates and were allowed to adhere in $\mathrm{CO}_{2}$ incubator at $37{ }^{\circ} \mathrm{C}$ for $24 \mathrm{~h}$. Then, cells were exposed to different concentrations $(10-1000 \mu \mathrm{g} / \mathrm{ml})$ of $V$. encelioides extract for $24 \mathrm{~h}$. After the exposure, $10 \mu \mathrm{l}$ of MTT $(5 \mathrm{mg} / \mathrm{ml}$ of stock) was added in each well and plates were incubated further for $4 \mathrm{~h}$. The supernatant was discarded and $200 \mu \mathrm{l}$ of DMSO was added in each well and mixed gently. The developed purple color was read at $550 \mathrm{~nm}$. Untreated sets run under identical conditions served as control.

\section{Cytotoxicity assessment by Neutral red uptake (NRU) \\ assay}

NRU assay was carried out following the protocol of Siddiqui et al. [28]. Briefly, 10,000 cells were plated in 96 well plates and were allowed to adhere in $\mathrm{CO}_{2}$ incubator at $37^{\circ} \mathrm{C}$ for $24 \mathrm{~h}$. Then, cells were exposed to different concentrations $(10-1000 \mu \mathrm{g} / \mathrm{ml})$ of $V$. encelioides for $24 \mathrm{~h}$. After the exposure, the medium was aspirated and cells were washed twice with PBS, and incubated for $3 \mathrm{~h}$ in a medium supplemented with neutral red $(50 \mu \mathrm{g} / \mathrm{ml})$. The medium was then washed off rapidly with a solution 
containing $0.5 \%$ formaldehyde and $1 \%$ calcium chloride. Cells were further incubated for $20 \mathrm{~min}$ at $37{ }^{\circ} \mathrm{C}$ in a mixture of acetic acid (1\%) and ethanol (50\%) to extract the dye. The plates were read at $550 \mathrm{~nm}$. The values were compared with the control sets.

\section{Morphological analysis by phase contrast microscope} Morphological alterations in A-549, MCF-7, and HepG2 cells exposed to $V$. encelioides extract were observed under microscope. All the cells were exposed to $10-1000 \mu \mathrm{g} / \mathrm{ml}$ of $V$. encelioides extract for $24 \mathrm{~h}$. The cell images were taken using an inverted phase contrast microscope at $20 \times$ magnification.

\section{Lipid peroxidation (LPO)}

Lipid peroxidation was performed using thiobarbituric acid-reactive substances (TBARS) protocol [29]. Briefly, $1 \times 10^{5}$ cells were plated in 6 well plates and were allowed to adhere in $\mathrm{CO}_{2}$ incubator at $37{ }^{\circ} \mathrm{C}$ for $24 \mathrm{~h}$. Then, cells were exposed to $250-1000 \mu \mathrm{g} / \mathrm{ml}$ of $V$. encelioides for $24 \mathrm{~h}$. After the exposure, HepG2 cells were collected by centrifugation. Then, cells were sonicated in ice cold potassium chloride (1.15 \%) and centrifuged at $3000 \times \mathrm{g}$ for $10 \mathrm{~min}$. Resulting supernatant $(1 \mathrm{ml})$ was added to $2 \mathrm{ml}$ of thiobarbituric acid (TBA) reagent (15\% TCA, $0.7 \%$ TBA and $0.25 \mathrm{NHCl}$ ) and was heated at $100{ }^{\circ} \mathrm{C}$ for $15 \mathrm{~min}$ in a boiling water bath. Samples were then placed in cold ice and were centrifuged at $1000 \times \mathrm{g}$ for $10 \mathrm{~min}$. The absorbance of the supernatant was measured at $550 \mathrm{~nm}$.

\section{Glutathione (GSH) content}

Intracellular GSH content was estimated as described [30]. Briefly, $1 \times 10^{5}$ cells were plated in 6 well plates and were allowed to adhere in $\mathrm{CO}_{2}$ incubator at $37{ }^{\circ} \mathrm{C}$ for $24 \mathrm{~h}$. Then, cells were exposed to $250-1000 \mu \mathrm{g} / \mathrm{ml}$ of $V$. encelioides for $24 \mathrm{~h}$. After the exposure, HepG2 cells were collected by centrifugation. The cellular protein was precipitated by incubating $1 \mathrm{ml}$ sonicated cell suspension with $1 \mathrm{ml}$ TCA (10\%) on ice for $1 \mathrm{~h}$, followed by $10 \mathrm{~min}$ centrifugation at $3000 \mathrm{rpm}$. Then, supernatant was added to $2 \mathrm{ml}$ of $0.4 \mathrm{M}$ Tris buffer ( $\mathrm{pH}$ 8.9) containing $0.02 \mathrm{M}$ EDTA, followed by an addition of

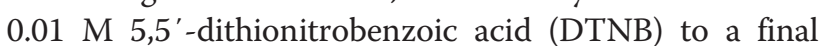
volume of $3 \mathrm{ml}$. The tubes were incubated at $37{ }^{\circ} \mathrm{C}$ for $10 \mathrm{~min}$ in a shaking water bath. The absorbance of the yellow color developed was read at $412 \mathrm{~nm}$.

\section{Reactive oxygen species (ROS) generation}

Intracellular ROS generation was detected using the fluorescent probe DCFH-DA dye, following the protocol described by Bakheet et al. [31]. In brief, $2 \times 10^{4}$ cells were plated in 24 well plates and were allowed to adhere in $\mathrm{CO}_{2}$ incubator at $37{ }^{\circ} \mathrm{C}$ for $24 \mathrm{~h}$. Then, cells were exposed to $250-1000 \mu \mathrm{g} / \mathrm{ml}$ of $V$. encelioides for $24 \mathrm{~h}$. After the exposure, HepG2 cells $(500 \mu \mathrm{l})$ were incubated in the dark with DCFH-DA $(5 \mu \mathrm{M})$ for $60 \mathrm{~min}$ at $37^{\circ} \mathrm{C}$. Then, cells were immediately washed twice with $\mathrm{PBS}$ and centrifuged at $3600 \times \mathrm{g}$ for $5 \mathrm{~min}$ at room temperature and cell pellets were further suspended in $500 \mu \mathrm{l} \mathrm{PBS}$. The fluorescence of cells was recorded under $488 \mathrm{~nm}$ excitation. Green fluorescence from DCF was measured in the FL1 Log channel through a $525 \mathrm{~nm}$ band-pass filter by a Beckman Coulter flow cytometer (Coulter Epics XL/Xl-MCL, USA). Data were presented as the mean fluorescence (MnXI) of 10,000 cells.

\section{Mitochondrial membrane potential (MMP)}

Flow cytometric measurements of MMP were performed following the method described by Bakheet et al. [31]. Briefly, $2 \times 10^{4}$ cells were plated in 24 well plates and were allowed to adhere in $\mathrm{CO}_{2}$ incubator at $37{ }^{\circ} \mathrm{C}$ for $24 \mathrm{~h}$. Then, cells were exposed to $250-1000 \mu \mathrm{g} / \mathrm{ml}$ of $V$. encelioides for $24 \mathrm{~h}$. After the exposure, control and treated cells were washed twice with PBS. Then the cells were further incubated with $5 \mu \mathrm{g} / \mathrm{ml}$ of mitochondrial specific fluorescent dye Rhodamine- 123 for $1 \mathrm{~h}$ at $37{ }^{\circ} \mathrm{C}$ in dark. Cells were then washed twice with PBS and finally responded in $500 \mu \mathrm{l}$ of PBS to measure the fluorescence intensity of Rhodamine- 123 . The intensity was measured using flow cytometry and expressed as the mean fluorescence intensity (MnXI) of 10,000 cells.

\section{Cell cycle analysis}

Cell cycle arrest was determined following the method [32]. In brief, $2 \times 10^{4}$ cells were plated in 24 well plates and were allowed to adhere in $\mathrm{CO}_{2}$ incubator at $37{ }^{\circ} \mathrm{C}$ for $24 \mathrm{~h}$. HepG2 cells were exposed to different concentrations $(250-1000 \mu \mathrm{g} / \mathrm{ml})$ of $V$. encelioides for $24 \mathrm{~h}$. After the exposure, cells were harvested and centrifuged at $3000 \mathrm{rpm}$ for $5 \mathrm{~min}$. Cell pellets were washed in $500 \mu \mathrm{l}$ of PBS. Then, cells were fixed with $500 \mu \mathrm{l}$ of chilled $70 \%$ ethanol, and further incubated at $4{ }^{\circ} \mathrm{C}$ for $1 \mathrm{~h}$. After two successive washes with PBS at $3000 \mathrm{rpm}$ for 5 min, cell pellets were suspended in PBS and stained with $50 \mu \mathrm{g}$ propiodium iodide (PI)/ml containing $0.1 \%$ Triton X-100 and $0.5 \mathrm{mg} / \mathrm{ml}$ RNAase A for $1 \mathrm{~h}$ at $30{ }^{\circ} \mathrm{C}$ in dark. Fluorescence of the PI was measured by flow cytometer using Beckman Coulter flow cytometer (Coulter Epics XL/Xl-MCL, Miami, USA) through a FL4 filter $(585 \mathrm{~nm})$. For the measurement, 10,000 events were acquired. The data were analyzed by Coulter Epics XL/XL-MCL, System II Software, Version 3.0. Cell debris characterized by a low FSC/SSC was excluded from the analysis. 


\section{DNA damage by comet assay}

DNA strand breaks in HepG2 cells exposed to different concentrations (250 to $1000 \mu \mathrm{g} / \mathrm{ml}$ ) of $V$. encelioides for $24 \mathrm{~h}$ were quantified by comet assay following the method described [32]. In brief, cells $\left(5 \times 10^{4}\right.$ cells/well $)$ were exposed to $V$. encelioides in 24 well plates for $24 \mathrm{~h}$ at $37^{\circ} \mathrm{C}$. The cells were washed with serum free medium and were harvested by adding $0.065 \%$ trypsin and incubated at $37{ }^{\circ} \mathrm{C}$. The cell suspension was centrifuged at $3000 \mathrm{rpm}$ for $5 \mathrm{~min}$ and the pellet was suspended in $100 \mu \mathrm{l}$ of PBS. The cells were mixed with $100 \mu \mathrm{l}$ of $1 \%$ LMA and were layered on one-third frosted slides, precoated with NMA (1\% in PBS) and kept at $4{ }^{\circ} \mathrm{C}$ for $10 \mathrm{~min}$. After gelling, another layer of $90 \mu \mathrm{l}$ of LMA $(0.5 \%$ in PBS) was added. The cells were lysed in a lysing solution overnight. After washing with TBE buffer, the slides were subjected to electrophoresis in cold TBE (Tris-base, $90 \mathrm{mM}$; boric acid, $90 \mathrm{mM}$; $\mathrm{Na}_{2}$ EDTA, $2.5 \mathrm{mM}$ ) buffer. Electrophoresis was performed at $1 \mathrm{~V} / \mathrm{cm}$ for $30 \mathrm{~min}(16 \mathrm{~mA}, 32 \mathrm{~V})$ at $4{ }^{\circ} \mathrm{C}$. All preparative steps were conducted in dark to prevent secondary DNA damage. Each slide was stained with $75 \mu \mathrm{l}$ of $20 \mu \mathrm{g} / \mathrm{ml}$ ethidium bromide solution for 5 min. The slides were analyzed at $40 \times$ magnification (excitation wavelength of 515-560 nm and emission wavelength of $590 \mathrm{~nm}$ ) using a fluorescence microscope (Nikon Eclipse 80i, Japan) coupled with a charge coupled device (CCD) camera. Images from 100 cells (50 from each replicate slide) were randomly selected and subjected to image analysis using software Comet Assay IV (Perceptive Instruments, Suffolk, UK).

\section{Statistical analysis}

Results are expressed as mean \pm standard error of three experiments. Statistical analysis was performed using one-way analysis of variance (ANOVA) and Post-hoc Dunnett's test was applied to compare values between control and treated groups. The values depicting $p<0.05$ were considered, as statistically significant.

\section{Results}

\section{Cytotoxicity assessment by MTT assay}

Figure 1 shows the results of cytotoxicity assessment of $V$. encelioides extract in A-549, MCF-7, and HepG2 cell lines obtained using MTT assay. A concentrationdependent decrease in cell viability was observed in HepG2 cells following $24 \mathrm{~h}$ of exposure to $V$. encelioides extract. The cell viability at concentrations of 250, 500 and $1000 \mu \mathrm{g} / \mathrm{ml}$ of $V$. encelioides extract was measured to be 90, 75 and 53 \% in HepG2 cells. Following exposure to 500 and $1000 \mu \mathrm{g} / \mathrm{ml}$ concentrations of $V$. encelioides extract, cell viability was measured to be 87 and $76 \%$ in MCF-7 cells. $V$. encelioides extract was less toxic to MCF-7 cells as compared to HepG2 cells and no cytotoxicity was found even at higher concentrations in A-549 cells (Fig. 1).

\section{Cytotoxicity assessment byNRU assay}

The results obtained using the NRU assay in $V$. encelioides extract treated A-549, MCF-7, and HepG2 cell lines are shown in Additional file 1: Figure S1. A concentration dependent decrease in the cell viability of HepG2 cells was observed following treatment with $V$. encelioides extract for $24 \mathrm{~h}$. The percentage cell viability, after exposure of 250, 500 and $1000 \mu \mathrm{g} / \mathrm{ml}$ of $V$. encelioides was measured to be 91,72 and $53 \%$ in HepG2 (Additional file 1: Figure S1). In MCF-7 cells, cell viability following treatment with 500 and $1000 \mu \mathrm{g} / \mathrm{ml}$ concentrations of $V$. encelioides extract was recorded as 83 and $72 \%$. However, A-549 cells treated with $V$. encelioides extract did not cause any decrease in the cell viability (Additional file 1: Figure S1). Like, MTT assay the effect of $V$. encelioides extract was found to be less toxic to MCF-7 cells as compared to the HepG2 cells and non-cytotoxic to A-549 cells (Additional file 1: Figure S1).

\section{Morphological changes}

Additional file 2: Figure S2 shows the morphological changes observed in A-549, MCF-7 and HepG2 cells exposed to different concentrations of $V$. encelioides for $24 \mathrm{~h}$. Morphological changes were observed using phase contrast inverted microscope. The cells exposed to higher doses of $V$. encelioides extract lost their normal morphology and shape; these cells appeared more rounded and less adherent than control. The HepG2 cells indicate the most prominent effects after the exposure of $V$. encelioides as compared to MCF-7 cells. However, A-549 cells exposed to $V$. encelioides extract did not cause any observable change in the normal morphology of the cells (Additional file 2: Figure S2).

\section{Lipid peroxidation}

Figure 2a summarizes the effect on lipid peroxidation level induced by $V$. encelioides extract in HepG2 cells. A concentration dependent statistically significant increase in lipid peroxidation was observed. An increase of 17, 39 , and $49 \%$ was recorded at 250, 500, and $1000 \mu \mathrm{g} / \mathrm{ml}$ of $V$. encelioides extract, respectively.

\section{Glutathione depletion}

Figure $2 b$ summarizes the decrease in the level of intracellular glutathione in HepG2 cells treated with 250-1000 $\mu \mathrm{g} / \mathrm{ml}$ concentrations of $V$. encelioides extract. The results indicate that $V$. encelioides extract decreased the glutathione level in a concentrationdependent manner. The decrease in GSH level was 


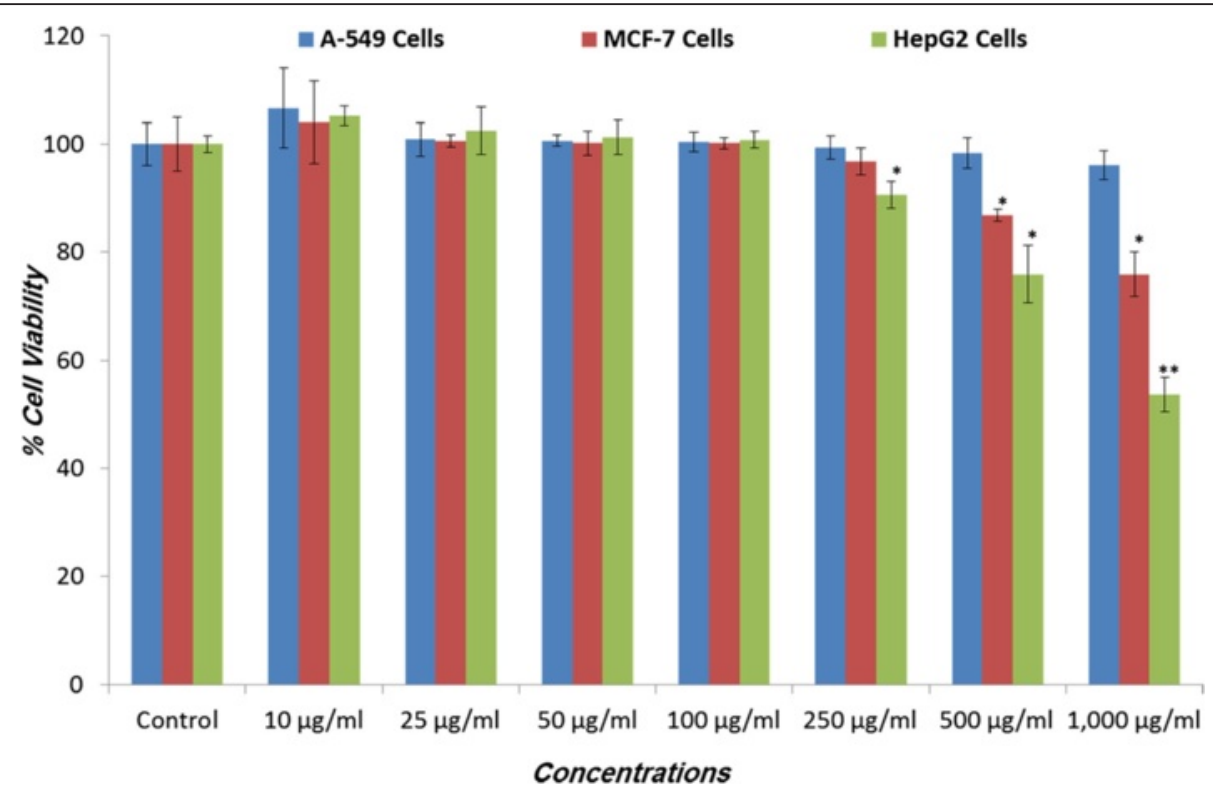

Fig. 1 Cytotoxicity assessments by MTT assay in A-549, MCF-7, and HepG2 cells. The cells were exposed to different concentrations of Verbesina encelioides extract for $24 \mathrm{~h}$. Values are the mean \pm SE of three independent experiments. ${ }^{*} p<0.05$ and ${ }^{* *} p<0.01$ versus Control

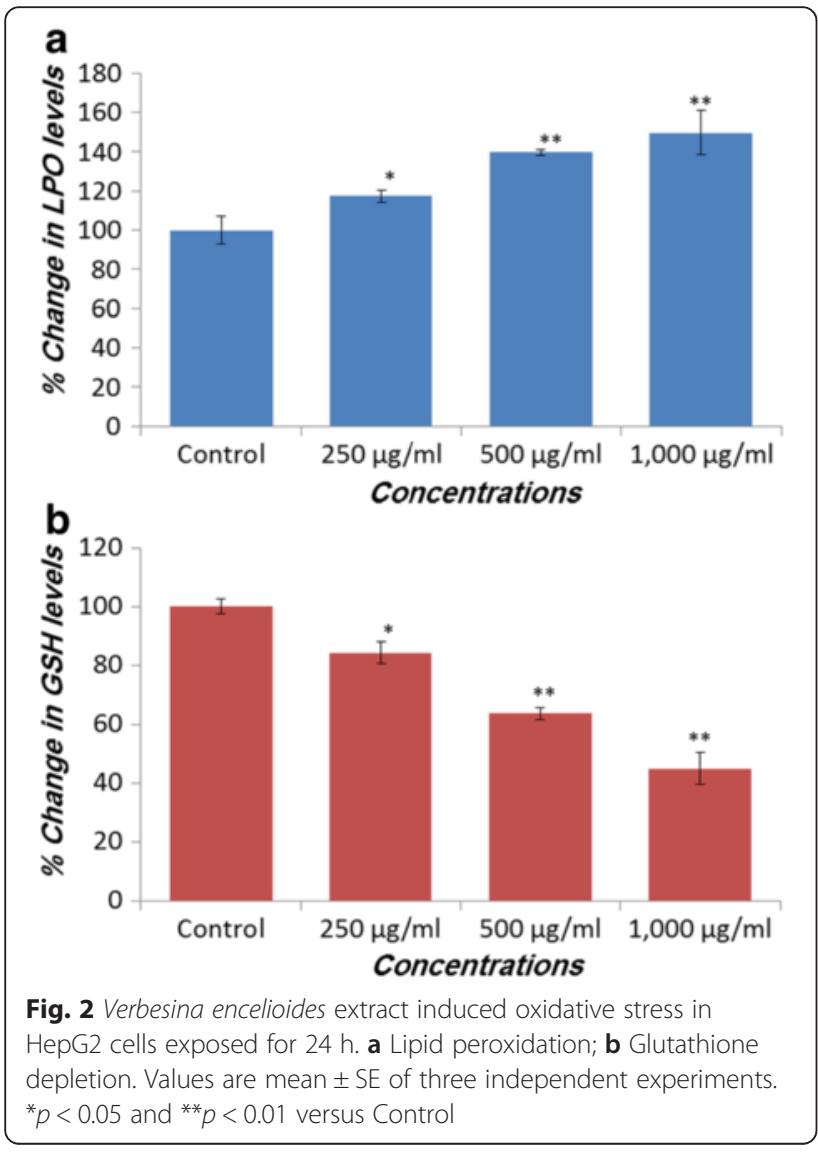

observed as 16, 37, and $56 \%$ at 250,500 , and $1000 \mu \mathrm{g} / \mathrm{ml}$ of $V$. encelioides, respectively as compared to the control (Fig. 2b).

\section{ROS generation}

Figure 3 shows the results obtained from ROS generation study. A statistically significant $(p<0.01)$ concentrationdependent ROS generation was observed in HepG2 cells treated with $V$. encelioides extract at 250, 500, and $1000 \mu \mathrm{g} / \mathrm{ml}$ concentrations for $24 \mathrm{~h}$. An increase of $154.63+17.55,150.69+3.2$, and $704.14=20.49 \%$ was observed in ROS generation at 250, 500, and $1000 \mu \mathrm{g} / \mathrm{ml}$, respectively, as compared to control. However, there was no significant increase observed between the $250 \mu \mathrm{g} / \mathrm{ml}$ and $500 \mu \mathrm{g} / \mathrm{ml}$ concentrations.

\section{Mitochondrial membrane potential (MMP)}

Figure 4 depicts the change in the level of MMP. The effect of $V$. encelioides exposure on MMP in HepG2 cells was evaluated. A concentration dependent statistically significant $(p<0.01)$ induction in the level of MMP was also observed in HepG2 cells after the exposure of $V$. encelioides for $24 \mathrm{~h}$. The induction in MMP was observed to be $128.84 \pm 3.8,129.91 \pm 3.6$, and $173.71 \pm 13.43 \%$ at 100,250 , and $500 \mu \mathrm{g} / \mathrm{ml}$ of $V$. encelioides, respectively as compared to untreated control (Fig. 4).

\section{Cell cycle analysis}

Figure 5 depicts the flow-cytometric analysis of cell cycle progression in HepG2 cells exposed to V. encelioides extract for $24 \mathrm{~h}$. Cell cycle analysis of propiodium iodide 

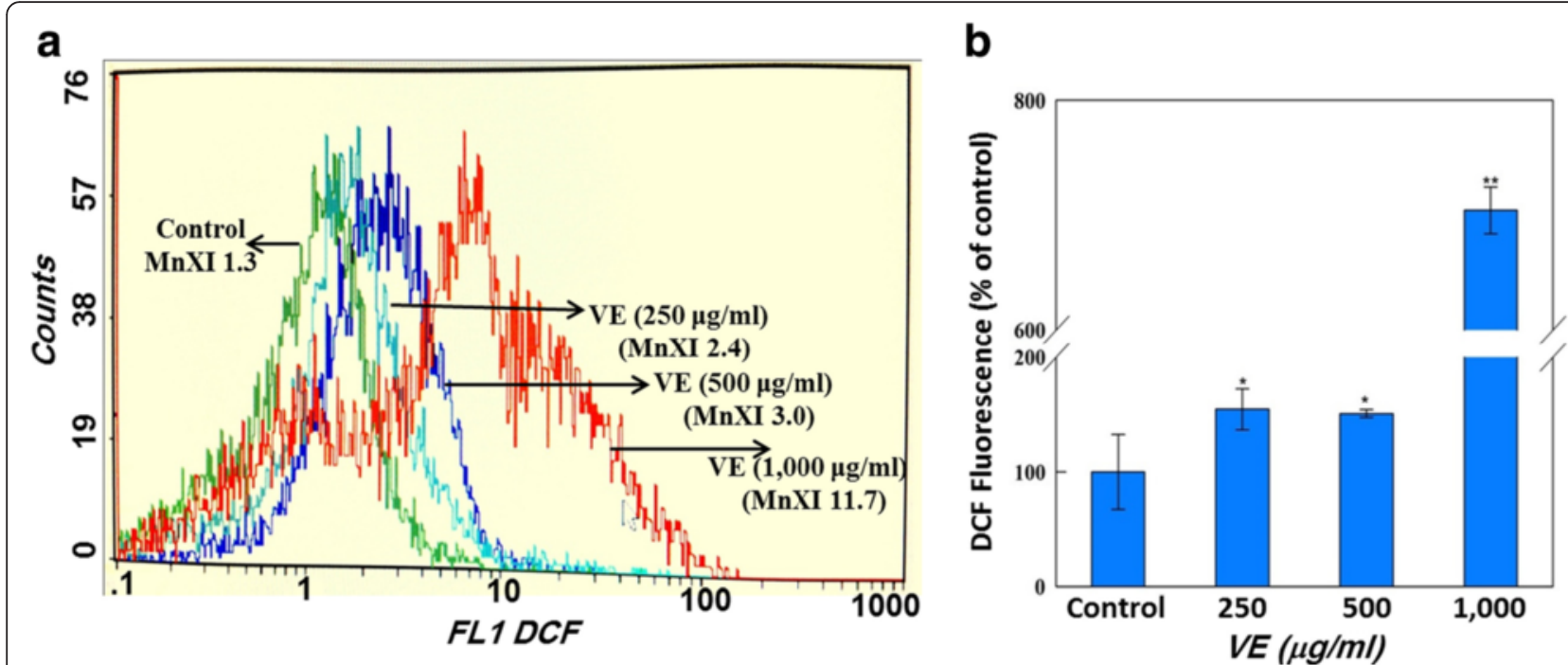

Fig. 3 Flow cytometric analysis of intracellular ROS generation in HepG2 cells exposed to Verbesina encelioides (VE) extract for $24 \mathrm{~h}$. Panel a shows the representative spectra of fluorescent DCF as a function of Verbesina encelioides extract concentration. Panel $\mathbf{b}$ exhibits the comparative analysis of the fluorescence enhancement of DCF with increasing concentrations of Verbesina encelioides extract. Each histogram represent the values of mean \pm SD of three independent experiments. ${ }^{*} p<0.05,{ }^{* *} p<0.01$ versus control

stained control and $V$. encelioides extract, treated HepG2 cells indicated an increase in apoptotic G2/M peak. At the highest concentration of $1000 \mu \mathrm{g} / \mathrm{ml} V$. encelioides treated cells showed a significant increase of $\sim 50 \%$ in G2/M arrest (Fig. 5).

\section{DNA damage by comet assay}

Table 1 summarizes the DNA damage measured by the comet assay parameters i.e., olive tail moment (OTM), tail length, and tail DNA intensity. The HepG2 cells exposed to $V$. encelioides extract for $24 \mathrm{~h}$ exhibited significant induction of DNA damage in a concentration dependent manner. The representative images of DNA damage obtained by the comet assay are shown in Fig. $6 \mathrm{a}$ and b. The HepG2 cells treated with 250,500 , and $1000 \mu \mathrm{g} / \mathrm{ml}$ of $V$. encelioides exhibited 2.86-, 3.13-, and 3.2-fold higher OTM values, 1.24-, 1.39, and 1.52-fold higher in tail length, and 1.9-, 2.1-, and 2.28-fold higher in tail DNA intensity (Table 1).
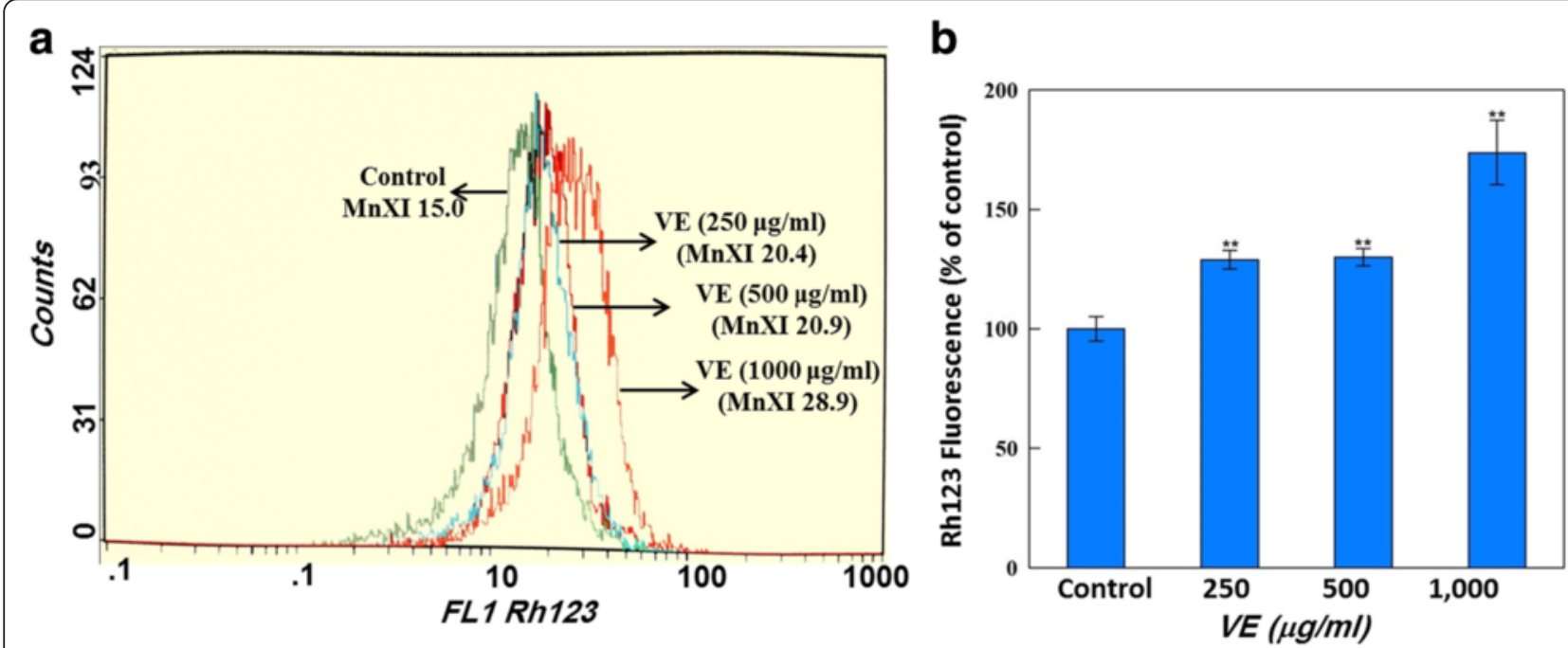

Fig. 4 Assessment of mitochondrial membrane potential in HepG2 cells exposed to Verbesina encelioides (VE) extract for 24 h. The fluorescence of Rh123was measured using a flow cytometer on log scale with FL1 filter. Panel a is a representative FACS image decline in the Rh123 fluorescence as a function of Verbesina encelioides extract concentrations. Each histogram in panel $\mathbf{b}$ represents mean \pm S.D. values of Rh123 fluorescence obtained from HepG2 cells exposed to varying concentrations of Verbesina encelioides extract. ${ }^{*} p<0.05,{ }^{* *} p<0.01$ versus control 

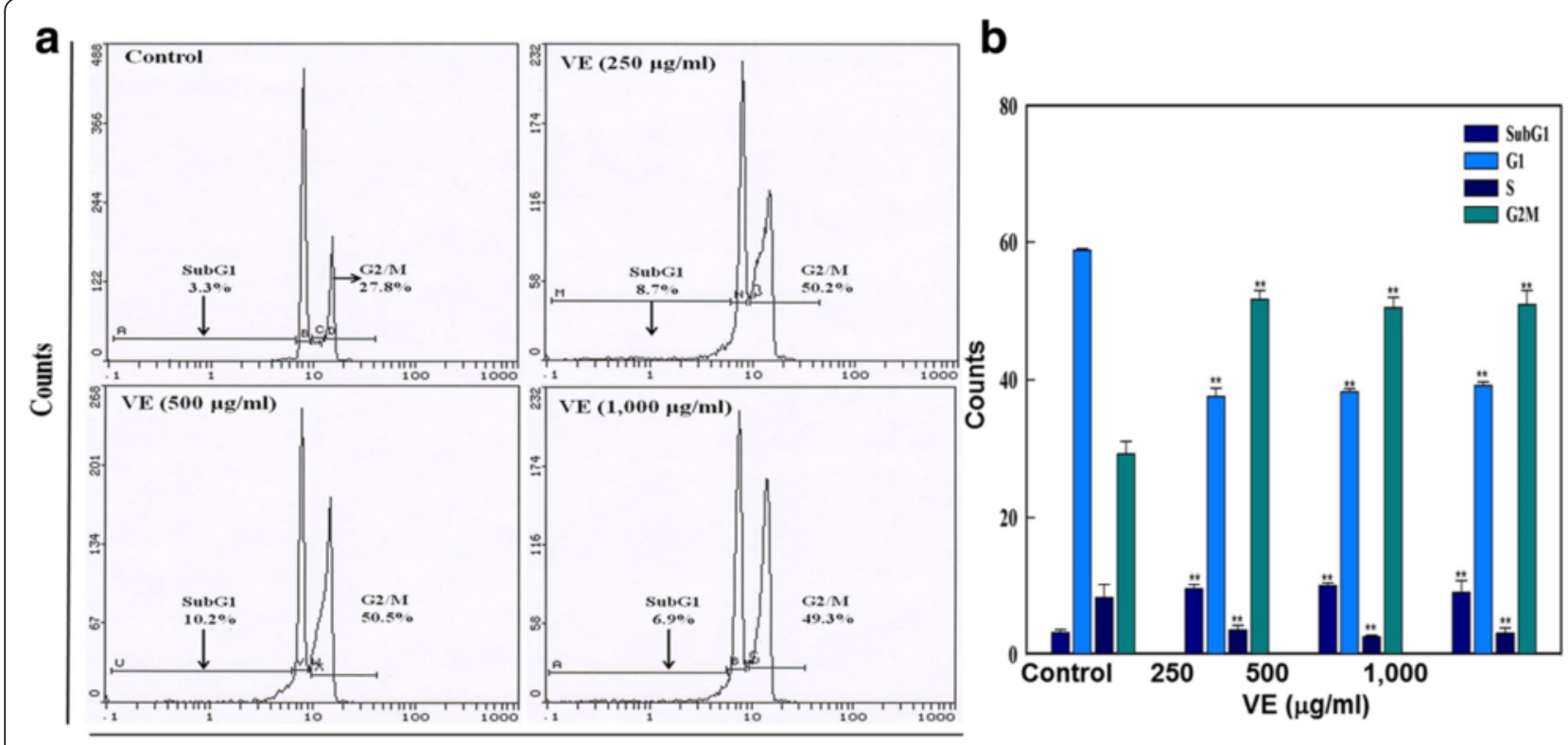

FL3 Log

Fig. 5 Cell cycle analysis in HepG2 cells exposed to $250-1000 \mu \mathrm{g} / \mathrm{ml}$ concentrations of $\mathrm{V}$. encelioides (VE) extract for 24 h. a Representative flow cytometric image exhibiting changes in the progression of cell cycle. G2/M in each micrograph represents the percentage of cells in the G2/M phase. $\mathbf{b}$ Each histogram represents the percentage of cells arrested in different phases of cell cycle. ${ }^{* *} p<0.001$ vs control

\section{Discussion}

Natural products are used for the treatment of various diseases since the beginning of human history. It has been estimated that approximately $80-85 \%$ of the world population rely on traditional medicines for their primarily health care and it is known that a major part of these therapies involves the use of plant extracts or their active components [17, 33, 34]. Most of the chemotherapy medicines to treat the cancer diseases are the molecules identified and isolated from plant materials or their synthetic analogs $[35,36]$. Though many researches have been explored for the advancement to protect cancer diseases, still there is a need to develop new drugs to improve the efficacy. The major disadvantages

Table $1 \mathrm{~V}$. encelioides (VE) extract induced DNA damage in HepG2 cells after $24 \mathrm{~h}$ of exposure, analyzed using different parameters of alkaline comet assay

\begin{tabular}{llll}
\hline Groups & $\begin{array}{l}\text { Olive tail moment } \\
\text { (Arbitrary unit) }\end{array}$ & $\begin{array}{l}\text { Tail length } \\
(\mu \mathrm{m})\end{array}$ & $\begin{array}{l}\text { Tail intensity } \\
(\%)\end{array}$ \\
\hline Control & $0.38 \pm 0.02$ & $34.96 \pm 3.87$ & $3.75 \pm 0.38$
\end{tabular}

VE extract $(\mu \mathrm{g} / \mathrm{ml})$

$\begin{array}{llll}250 & 1.09 \pm 0.09^{*} & 43.50 \pm 2.45^{*} & 7.24 \pm 0.98^{*} \\ 500 & 1.19 \pm 0.07^{*} & 48.55 \pm 3.12^{*} & 7.84 \pm 0.87^{*} \\ 1000 & 1.23 \pm 0.14^{*} & 53.26 \pm 4.56^{*} & 8.55 \pm 0.99^{*}\end{array}$

Data represent the mean \pm S.D. of three independent experiments done in duplicate. ${ }^{*} p<0.05$ vs. control. Statistical analysis was performed by one-way analysis of variance (ANOVA) using Dunnett's multiple comparisons test. The level of statistical significance chosen was $p<0.05$, unless otherwise stated of available synthetic drugs are their association with the side effects [37]. Natural therapy, such as use of the plant products have proved beneficial against the cancer diseases $[38,39]$. Thus, there is a constant demand to develop effective new anticancer drugs at affordable cost $[36,40]$. Over the last 30 years, natural products have received increasing attention for their potential as new cancer preventive agents [41, 42]. Bearing these facts in mind, we aimed to examine the anticancer potential of $V$. encelioides against three human cancer cell lines, i.e. lung cancer (A-549), breast cancer (MCF-7), and liver cancer (HepG2). Further, oxidative stress (GSH and $\mathrm{LPO}$ ), reactive oxygen species (ROS) generation, mitochondrial membrane potential (MMP), cell cycle arrest, and DNA damage were also assessed against liver cancer (HepG2) cells. The results of MTT and NRU assay showed that the $V$. encelioides extract exhibited a concentration-dependent cytotoxic response. The MTT and NRU assays are commonly used endpoints for cytotoxicity assessments, since they evaluate different aspects of cellular functions and, therefore, can be useful to examine the potential cytotoxic effects of plant extracts. Estimation of cytotoxicity is generally based on uptake or exclusion of dye and are an indicator of the integrity of the plasma membrane or some intracellular organelles. However, the MTT assay indicates the mitochondrial function based on the enzymatic reduction of a tetrazolium salt by the mitochondrial dehydrogenase of viable cells [43]. NRU is a measure of lysosomal integrity 

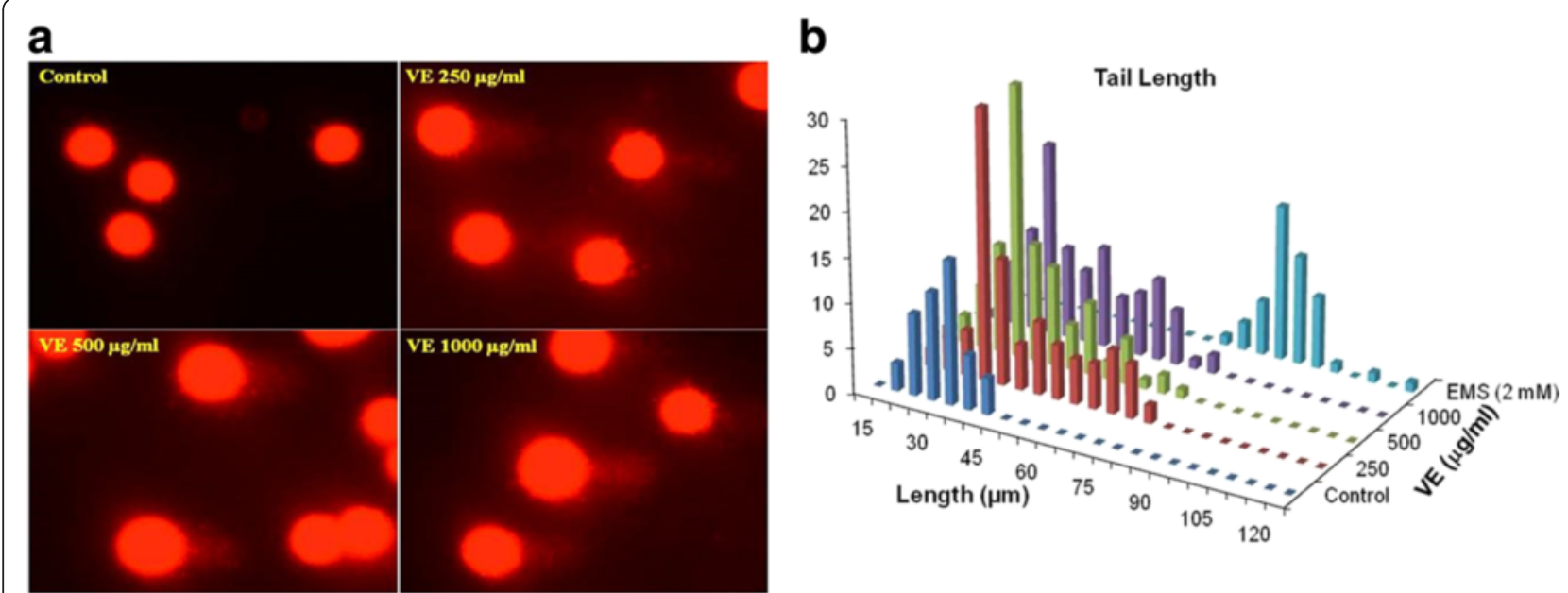

Fig. 6 Verbesina encelioides extract (VE) induced strand breaks in cellular DNA of HepG2 cells. a Representative epi-fluorescence images of DNA damage in comet assay. $\mathbf{b}$ Percent distribution of DNA damage in HepG2 cells exposed to varying concentrations of Verbesina encelioides extract (VE) for $24 \mathrm{~h}$. Olive tail moment (OTM) values were determined following the algorithm (Olive Tail Moment = (Tail Mean - Head Mean) Tail \% DNA/100) using Comet Assay IV software. ${ }^{* *} p<0.01$ versus control

since it reflects the capacity of viable cells to incorporate vital dye into these organelles [44].

The decrease in the cell viability found was specifically towards MCF-7 and HepG2 cells, whereas no effect was observed on A-549 cells. Further, the cytotoxic response was more in HepG2 cells as compared to MCF-7 cells. The differential cytotoxic response of the $V$. encelioides might be due to the specificity of plant towards different cancer cells, as has been reported previously [45, 46]. Our results are well in ordinance with the other findings where these kinds of effects are due to the presence of active components [47]. Our present study demonstrated that $V$. encelioides extract showed promising anti-cancer activity. However, activity was less in MCF-7 cells as compared to HepG2 cells. Thus, HepG2 cells were selected as a model to further investigate the underlying mechanism (s) responsible, for this cytotoxic response. An observable concentration dependent statistically significant increase in lipid peroxidation occurred. An increase of 17, 39, and $49 \%$ was observed at 250, 500 , and $1000 \mu \mathrm{g} / \mathrm{ml}$ of $V$. encelioides extract, respectively. Oxidative stress is involved in normal cellular processes of cell signaling [48]. Many studies have shown that exposure to natural products promotes cellular oxidative stress which includes lipid peroxidation and depletion in glutathione levels [49, 50]. Data from this study also showed that $V$. encelioides induced oxidative stress in HepG2 cells in a concentration-dependent manner. An increase in the level of lipid peroxidation and a decrease in the antioxidant enzyme GSH were observed. These findings suggest that oxidative stress may be the primary mechanism of the cell death in HepG2 cells when exposed to $V$. encelioides extract. Previous reports, suggesting the role of oxidative stress in the cell death induced by plant extracts [51, 52] firmly support our results. One of the most common cytotoxic effects in cancer cells is due to the induction of reactive oxygen species (ROS) generation [53]. We found that HepG2 cells exposed to $V$. encelioides extract significantly increased intracellular ROS generation in a concentrationdependent manner. Our results are also in agreement with previous findings, where researchers showed ROS induction due to the treatment of plant extracts $[54,55]$. We found an induction in the MMP level in HepG2 cells treated with $V$. encelioides extract for $24 \mathrm{~h}$. Reports suggest that high levels of ROS can lead to cellular damage by resulting in mitochondrial damage, which can then induce cell death [32]. Induction in MMP level, based on cationic fluorescent probe Rh123 indicate the role of oxidative stress and ROS generation in cell death of HepG2 cells, due to the generation of free radicals during the mitochondrial respiration. The results from this study confirmed that HepG2 cells treated with $V$. encelioides extract for $24 \mathrm{~h}$ significantly activate the G2/M cell cycle checkpoint as observed by flow-cytometry. Reports reveal that p53 protein is regarded as the guardian of the cell genome and is able to activate cell cycle checkpoints, DNA repair and apoptosis to maintain stability of genome [56]. Flow cytometry analysis of $V$. encelioides extract treated HepG2 cells suggests the activation of DNA repair process as observed by cell cycle arrest in G2/M phase at 250, 500, and $1000 \mu \mathrm{g} / \mathrm{ml}$ concentration of $V$. encelioides. It is also known that the DNA repair mechanisms in the cells are highly conserved, thus the extensive DNA damage may lead to cell-cycle arrest and cell death as observed in this 
investigation. We have highlighted the DNA damaging potential of $V$. encelioides extract in HepG2 cells by comet assay. The results of Table 1 revealed that the $V$. encelioides extract induced a concentration-dependent significant DNA damage as observed by the induction in the fold change of olive tail moment (OTM), tail length, and tail DNA intensity. This $V$. encelioides extract induced DNA damage can be explained on the basis of the experimental evidence of genotoxic potential in HepG2 cells. The DNA damage may either lead to apoptotic cell death or disrupt the factionalizing of cells [57-59]. The DNA damage induced in HepG2 cells indicates the presence of bioactive components in $V$. encelioides extract that are capable of oxidative DNA damage in cancer cells through their pro-oxidant mechanism.

\section{Conclusion}

The findings from this study, for the first time provide new understandings on the anticancer potential of Verbesina encelioides. $V$. encelioides extract exhibited differential cytotoxic responses in A-549, MCF-7, and HepG2 cell lines. The $V$. encelioides extract exhibit high cytotoxic response in HepG2 cells as compared to MCF7 cells and proved non-cytotoxic in A-549 cells. Results from this study also entrenched the capacity of $V$. encelioides extract to induce apoptotic cell death in human liver cancer (HepG2) cells through oxidative stress, ROS generation, cell cycle arrest, and DNA damage. Our results suggest that $V$. encelioides extract has promising anticancer potential. Therefore, it can be further used to develop a new anticancer agent to treat the deadly cancer diseases.

\section{Ethics approval and consent to participate}

This information is not relevant.

\section{Consent for publication}

This information is not relevant.

\section{Availability of data and materials}

The datasets supporting the conclusions of this article are included within the article and its additional files.

\section{Additional files}

Additional file 1:Figure S1. Cytotoxicity assessments by NRU assay in A-549, MCF-7, and HepG2 cells. The cells were exposed to different concentrations of Verbesina encelioides extract for $24 \mathrm{~h}$. Values are the mean \pm SE of three independent experiments. ${ }^{*} p<0.05$ and ${ }^{* *} p<0.01$ versus Control. (JPG 394 kb)

Additional file 2: Figure S2. Morphological changes in A-549, MCF-7, and HepG2 cells. The cells were exposed to different concentrations of Verbesina encelioides extract for $24 \mathrm{~h}$. Images were taken using an inverted phase contrast microscope at 20x magnification. (JPG $384 \mathrm{~kb}$ )

\section{Abbreviations}

\%: percentage; ${ }^{\circ} \mathrm{C}$ : degree celsius; A-549: human lung cancer cell line; $\mathrm{CO}_{2}$ : carbon dioxide; DCFH-DA: dichloro-dihydro-fluorescein diacetate; DMEM: Dulbecco's modified eagle's medium; DMSO: dimethylsulphoxide; DNA: deoxyribonucleic acid; DTNB: (5,5-dithio-bis-(2-nitrobenzoic acid); EDTA: ethylenediaminetetraacetic acid; FBS: fetal bovine serum; GSH: glutathione; H: hour; $\mathrm{HCl}$ : hydrochloric acid; HepG2: human liver cancer cell line; L: liter; LMA: low melting agarose; LPO: lipid peroxidation; MCF-7: human breast cancer cell line; $m g$ : milligram; $\mathrm{ml}$ : milliliter; MMP: mitochondrial membrane potential; MTT: 3-(4, 5-dimethylthiazol-2yl)-2, 5-diphenyl tetrazolium bromide; nm: nanometers; NMA: normal melting agarose; NRU: neutral red uptake; PBS: phosphate buffer saline; pH: potential of hydrogen; PI: propiodium iodide; Rh 123: rhodamine-123; RNAase: ribonuclease; ROS: reactive oxygen species; TBA: thiobarbituric acid TBE: tris/borate/EDTA; TCA: trichloroacetic acid; VE: Verbesina encelioides; $\mu g$ : microgram; $\mu$ : microliter.

\section{Competing interests}

The authors declare that they have no competing interests.

\section{Authors' contributions}

NNF and MAS conceived of and designed the experiments. NNF, MAS, QS, MMA and ESA performed the experiments. MAS, NNF, QS, MMA, ESA, and JM analyzed the data. MMA and AAA contributed reagents/materials/analysis tools. NNF and MAS wrote the paper. All authors read and approved the final manuscript.

\section{Acknowledgments}

This project was financially supported by King Saud University, Vice Deanship of Research Chairs.

\section{Funding}

This project was financially supported by King Saud University, Vice Deanship of Research Chairs.

\section{Author details}

${ }^{1}$ Department of Pharmacognosy, College of Pharmacy, King Saud University, Riyadh 11451, Kingdom of Saudi Arabia. ${ }^{2}$ Zoology Department, College of Science, King Saud University, P.O. Box-2455, Riyadh 11451, Kingdom of Saudi Arabia. ${ }^{3} \mathrm{Al}$-Jeraisy Chair for DNA Research, Zoology Department, College of Science, King Saud University, Riyadh 11451, Kingdom of Saudi Arabia.

Received: 24 November 2015 Accepted: 30 April 2016

Published online: 10 May 2016

\section{References}

1. Jemal A, Siegel R, Xu J, Ward E. Cancer statistics, 2010. CA Cancer J Clin. 2010;60:277-300.

2. Sylla BS, Wild CP. A million africans a year dying from cancer by 2030: what can cancer research and control offer to the continent? Int J Cancer. 2012;130:245-50.

3. Iweala EEJ, Liu F-F, Cheng R-R, Li Y, Omonhinmin CA, Zhang Y-J. Anti-cancer and free radical scavenging activity of some Nigerian food plants in vitro. Int J Cancer Res. 2015:11:41-51.

4. Vorobiof DA, Abratt R. The cancer burden in Africa. S Afr Med J. 2007;97:937-9.

5. World Health Organization. World Health Organization: cancer fact sheet. 2011. http://www.who.int/mediacentre/factsheets/fs297/en/. Accessed 5 Feb 2015.

6. World Health Organization. Health statistics and information systems: WHO mortality database. http://www.who.int/healthinfo/mortality_data/en/. Accessed 6 Nov 2014

7. Galaal K, van der Heijden E, Godfrey K, Naik R, Kucukmetin A, Bryant A, Das $\mathrm{N}$, Lopes AD. Adjuvant radiotherapy and/or chemotherapy after surgery for uterine carcinosarcoma. Cochrane Database Syst Rev. 2013;2, CD006812.

8. Shylasree TS, Bryant A, Athavale R. Chemotherapy and/or radiotherapy in combination with surgery for ovarian carcinosarcoma. Cochrane Database Syst Rev. 2013;2, CD006246.

9. Fadeyi SA, Fadeyi OO, Adejumo AA, Okoro C, Myles EL. In vitro anticancer screening of 24 locally used Nigerian medicinal plants. BMC Complement Altern Med. 2013;13:79. 
10. Al-Sheddi ES, Farshori NN, Al-Oqail MM, Musarrat J, Al-Khedhairy AA, Siddiqui MA. Portulaca oleracea seed oil exerts cytotoxic effects on human liver cancer (HepG2) and human lung cancer (A-549) cell lines. Asian Pac J Cancer Prev. 2015;16:3383-7.

11. Kim J, Park EJ. Cytotoxic anticancer candidates from natural resources. Curr Med Chem Anticancer Agents. 2002;2:485-537.

12. Mann J. Natural products in cancer chemotherapy: past, present and future. Nat Rev Cancer. 2002;2:143-8.

13. Svejda B, Aguiriano-Moser V, Sturm S, Hoger H, Ingolic E, Siegl V, Stuppner H, Pfragner R. Anticancer activity of novel plant extracts from Trailliaedoxa gracilis (W. W. Smith \& Forrest) in human carcinoid KRJ-I cells. Anticancer Res. 2010;30:55-64

14. Khan MA, Chen HC, Tania M, Zhang DZ. Anticancer activities of Nigella sativa (black cumin). Afr J Tradit Complement Altern Med. 2011;8:226-32.

15. Randhawa MA, Alghamdi MS. Anticancer activity of Nigella sativa (black seed) - a review. Am J Chin Med. 2011;39:1075-91.

16. Sharma JVC, Pitchaiah G, Satyavati D, Rao JV, Kumar HS, Vikram. In vitro anticancer activity of methanolic extract of roots of Glochidionzeylanicum (Gaertn). IJRPBS. 2011;2:760-4.

17. Prakash O, Kumar A, Kumar P, Ajeet. Anticancer potential of plants and natural products: a review. Am J Pharmacol Sci. 2013;1:104-15.

18. Gautam N, Mantha AK, Mittal S. Essential oils and their constituents as anticancer agents: a mechanistic view. Biomed Res Int. 2014;2014:154106.

19. Feenstra KR, Clements DR. Biology and impacts of Pacific island invasive species. 4. Verbesina encelioides, golden crownbeard (Magnoliopsida: Asteraceae). Pac Sci. 2008;62:161-76.

20. Jain SC, Purohit M, Sharma R. Pharmacological evaluation of Verbesina encelioides. Phytother Res. 1988;2:146-8.

21. Stepp JR, Moerman DE. The importance of weeds in ethnopharmacology. J Ethnopharmacol. 2001;75:19-23.

22. Joshi KC, Singh $P$, Singhi CL. Chemical constituents of Verbesina encelioides and Holmkioldia sanguine. J Chem Soc. 1983;60:905-6.

23. GlennieCW JSC. Flavones 3,7-diglycosides of Verbesina encelioides. Phytochemistry. 1980;19:157-8.

24. Oelrichs PB, Vallely PJ, MacLeod JK, Lewis IAS. Isolation of galegine from Verbesina encelioides. J Nat Prod. 1981:44:754-5.

25. Tiwari H, Rao P, Sambasiva V. Constituents of Verbesina encelioides: isolation of triterpenoids from a Verbesina species. Indian J Chem. 1978;16:1133.

26. Pant AB, Agarwal AK, Sharma VP, Seth PK. In vitro cytotoxicity evaluation of plastic biomedical devices. Hum Exp Toxicol. 2001;20:412-7.

27. Al-Sheddi ES, Al-Oqail MM, Saquib Q, Siddiqui MA, Musarrat J, Al-Khedhairy AA, Farshori NN. Novel all trans-retinoic acid derivatives: cytotoxicity, inhibition of cell cycle progression and induction of apoptosis in human cancer cell lines. Molecules. 2015;20:8181-97.

28. Siddiqui MA, Kashyap MP, Kumar V, Al-Khedhairy AA, Musarrat J, Pant AB Protective potential of trans-resveratrol against 4-hydroxynonenal induced damage in PC12 cells. Toxicol In Vitro. 2010;24:1592-8.

29. Buege JA, Aust SD. Microsomal lipid peroxidation. Methods Enzymol. 1978:52:302-10

30. Chandra D, Ramana KV, Wang L, Christensen BN, Bhatnagar A, Srivastava SK. Inhibition of fiber cell globulization and hyperglycemia-induced lens opacification by aminopeptidase inhibitor bestatin. Invest Ophthalmol Vis Sci. 2002:43:2285-92

31. Bakheet SA, Attia SM, Al-Rasheed NM, Al-Harbi MM, Ashour AE, Korashy HM, Abd-Allah AR, Saquib Q, Al-Khedhairy AA, Musarrat J. Salubrious effects of dexrazoxane against teniposide-induced DNA damage and programmed cell death in murine marrow cells. Mutagenesis. 2011;26:533-43.

32. Siddiqui MA, Saquib Q, Ahamed M, Farshori NN, Ahmad J, Wahab R, Khan ST, Alhadlaq HA, Musarrat J, Al-Khedhairy AA, Pant AB. Molybdenum nanoparticlesinduced cytotoxicity, oxidative stress, G2/M arrest, and DNA damage in mouse skin fibroblast cells (L929). Colloids Surf B: Biointerfaces. 2015;125:73-81.

33. Tomlinson TR, Akerele O. Medicinal plants: their role in health and biodiversity. Philadelphia: University of Pennsylvania Press; 1998

34. Elujoba AA, Odeleye OM, Ogunyemi CM. Traditional medicine development for medical and dental primary health care delivery system in Africa. Afr J Tradit Complement Altern Med. 2005;2:46.

35. Cragg GM, Newman DJ. Natural products: a continuing source of novel drug leads. Biochim Biophys Acta. 1830;2013:3670-95.

36. Solowey E, Lichtenstein M, Sallon S, Paavilainen H, Solowey E, LorberboumGalski H. Evaluating medicinal plants for anticancer activity. Sci World J. $2014 ; 2014: 721402$
37. Chiappelli F, Ramchandani MH, Singh RH. Evidence-based practice in complementary and alternative medicine: perspectives, protocols, problems and potential. In: Rastogi AS, editor. Berlin Heidelberg: Springer Science \& Business Media; 2012.

38. Cassileth BR, Deng G. Complementary and alternative therapies for cancer. Oncologist. 2004;9:80-9.

39. Yin SY, Wei WC, Jian FY, Yang NS. Therapeutic applications of herbal medicines for cancer patients. Evid Based Complement Alternat Med. 2013;2013:302426.

40. Coseri S. Natural products and their analogues as efficient anticancer drugs. Mini Rev Med Chem. 2009;9:560-71.

41. Newman DJ. Natural products as leads to potential drugs: an old process or the new hope for drug discovery? J Med Chem. 2008;51:2589-99.

42. Newman DJ, Cragg GM, Snader KM. Natural products as sources of new drugs over the period 1981-2002. J Nat Prod. 2003;66:1022-37.

43. Borenfreund E, Puerner JA. Short-term quantitative in vitro cytotoxicity assay involving an S-9 activating system. Cancer Lett. 1987;34:243-8.

44. Mosmann T. Rapid colorimetric assay for cellular growth and survival: application to proliferation and cytotoxicity assays. J Immunol Methods. 1983;65:55-63.

45. Mishra A, Kumar S, Pandey AK. Scientific validation of the medicinal efficacy of Tinosporacordifolia. Sci World J. 2013;2013:292934

46. Sak K. Cytotoxicity of dietary flavonoids on different human cancer types. Pharmacogn Rev. 2014;8:122-46.

47. Kumar S, Pandey AK. Chemistry and biological activities of flavonoids: an overview. Sci World J. 2013;2013:162750.

48. Rahal A, Kumar A, Singh V, Yadav B, Tiwari R, Chakraborty S, Dhama K Oxidative stress, prooxidants, and antioxidants: the interplay. Biomed Res Int. 2014;2014:761264

49. Grigutytė R, Nimptsch J, Manusadžianas L, Pflugmacher S. Response of oxidative stress enzymes in charophyte Nitellopsisobtusa exposed to allochthonous leaf extracts from beech Fagus sylvatica. Biologija. 2009:55:142-9.

50. Abdullah AS, Mohammed AS, Rasedee A, Mirghani ME. Oxidative stressmediated apoptosis induced by ethanolic mango seed extract in cultured estrogen receptor positive breast cancer MCF-7 cells. Int J Mol Sci. 2015:16:3528-36.

51. Tor YS, Yazan LS, Foo JB, Armania N, Cheah YK, Abdullah R, Imam MU, Ismail $\mathrm{N}$, Ismail M. Induction of apoptosis through oxidative stress-related pathways in MCF-7, human breast cancer cells, by ethyl acetate extract of Dillenia suffruticosa. BMC Complement Altern Med. 2014;14:55.

52. Farshori NN, Al-Sheddi ES, Al-Oqail MM, Hassan WH, Al-Khedhairy AA, Musarrat J, Siddiqui MA. Hepatoprotective potential of Lavandula coronopifolia extracts against ethanol induced oxidative stress-mediated cytotoxicity in HepG2 cells. Toxicol Ind Health. 2015;31:727-37.

53. Liou GY, Storz P. Reactive oxygen species in cancer. Free Radic Res. 2010;44:479-96

54. Karimi M, Conserva F, Mahmoudi S, Bergman J, Wiman KG, Bykov VJ. Extract from Asteraceae Brachylaena ramiflora induces apoptosis preferentially in mutant p53-expressing human tumor cells. Carcinogenesis. 2010;31:1045-53.

55. Ghali W, Vaudry D, Jouenne T, Marzouki MN. Extracts from medicinal plants inhibit cancer cell proliferation, induce apoptosis in ovary, lung and neuronal cancer cell lines. Cancer Metab. 2014;2:1-2

56. Sherr CJ. Principles of tumor suppression. Cell. 2004;116:235-46.

57. Mounira K, Nouha N, Imen M, Kamel G, Leila CG. Limoniastrum guyonianum extracts induce apoptosis via DNA damage, PARP cleavage and UHRF1 down-regulation in human glioma U373 cells. J Nat Prod. 2014;7:79-86.

58. Paul S, Chakraborty S, Mukherjee A, Kundu R. Evaluation of cytotoxicity and DNA damaging activity of three plant extracts on cervical cancer cell lines. Int J Pharm Sci Rev Res. 2015:31:183-9.

59. Koňariková K, Ježovičová M, Keresteš J, Gbelcová H, Duuračková Z, Žitňanová I. Anticancer effect of black tea extract in human cancer cell lines. Springer Plus. 2015:4:1-6. 